\title{
STUDIES ON THE MOLLUSCICIDAL ACTIVITY OF AGAVE ANGUSTI- FOLIA AND PITTOSPORUM TOBIRA ON SCHISTOSOMIASIS TRANSMITTING SNAILS \\ By
}

\author{
ABDALLA M. IBRAHIM ${ }^{1}$, MAHFOUZ M. ABDEL-GAWAD', \\ HANAN A. EL-NAHAS ${ }^{2}$ AND NADIA S. OSMAN ${ }^{*}$ \\ Department of Zoology ${ }^{1}$, Faculty of Science, Ain Shams University, Cairo \\ 11566, and Department of Medicinal Chemistry ${ }^{2}$, Theodor Bilharz Research \\ Institute, Imbaba P.O. Box 30, Giza, Egypt ("Correspondence: E-mail: nadi- \\ asayed1255@gmail.com; Tel: +2 01287605285; Fax: +2 023540 8125).
}

\section{Abstract}

In the search for new molluscicidal plants for controlling the snail vectors of schistosomiasis, laboratory evaluation was made to assess the molluscicidal activity of Agave angustifolia and Pittosporum tobira plants against Biomphalaria alexandrina snails. Results indicated that both plants have promising molluscicidal activity as the $\mathrm{LC}_{90}$ of the dry powder of both plants was $120 \mathrm{ppm}$. Both plants showed marked cercaricidal and miracidicidal potencies against $S$. mansoni larvae. The $\mathrm{LC}_{90}$ of both plants $(120 \mathrm{ppm})$ killed most $B$. alexandrina eggs within $24 \mathrm{~h}$ of exposure. The sub-lethal concentrations of both plants markedly suppressed the survival rate of $B$. alexandrina snails and the mortality increased with increasing the concentrations and the exposure period up to 10 successive weeks.

The accumulative toxic effect of these concentrations was continuous during the recovery period. Also, the reproductive rates of exposed snails were greatly affected even through the recovery period. This depression in reproductive ability of snails was accompanied by histological damage in the hermaphrodite glands of exposed snails. Meanwhile, the growth of snails was estimated weekly and it showed great inhibition in exposed snails comparing with the control ones.

Keywords: Molluscicidal plants; Agave angustifolia; Pittosporum tobira; Schistosomiasis

\section{Introduction}

Schistosomiasis is a parasitic disease from which more than 300 million people suffer throughout South America, Africa and the Far East. The disease is a public health problem and is endemic in Egypt and many other areas of the world (Abebe et al, 2005; Silva et al, 2005; Mortada et al, 2011; Abdalla et al, 2012; Fayez et al, 2013; Ahmed et al, 2014). Transmission of the disease requires contact with water sources which harbor aquatic snails. Control of this disease could be conducted through chemotherapy, health education, environmental sanitation and snail control. Chemotherapy with orally administered anti-schistosomal drugs is the most widely used method. Focal treatment of fresh water sites with molluscicides is a simple and inexpensive method of removing the snail vectors which are indispensable for the life cycle of the parasite. Thus, an extensive search for suitable molluscicides that can be used in the treatment of snail-infested sites in endemic areas has been pursued (Sparg et al, 2000; Adewunmi and Aldaesanmi, 2006; Fayez et al., 2013). Since the discovery of highly potent saponins in Phytolacca dodecandra berries in the $19601 \mathrm{~s}$, naturally occurring molluscicides has received considerable attention and the number of reports on the evaluation of plant-derived molluscicides has increased considerably (Singh et al, 2005; Medina et al, 2009; El-Sayed et al, 2011; Abdalla et al, 2012; Fayez et al, 2013).

In the search for new plant molluscicides, a wide range of indigenous plants especially those of common use in folk 
medicine were screened for molluscicidal activity (Abdel Kader et al, 2005; Mostafa et al, 2005; El-Sayed et al, 2011). In Egypt, screening of local plants for molluscicidal potency has received considerable attention since the molluscicidal activity of the Egyptian plant; Ambrosia maritima $L$. was first reported. A. mariti$m a$ at $1000 \mathrm{ppm}$ was lethal to $B$. truncatus after 24 hrs but killed miracidia and cercariae after $30 \mathrm{~min}$. When plant was applied in the field at $70 \mathrm{ppm}$ for 7 weeks, it reduced snail's population (Abd Allah, 2009; Mortada et al, 2014).

This study was carried out to investigate two plants, A. angustifolia (Agavaceae) and $P$. tobira (Pittosporaceae) as molluscicidal, ovicidal and larvicidal potencies against Biomphalaria alexandrina and $S$. mansoni larvae. The effect of prolonged exposure to sublethal concentrations of the two plants was also evaluated on some biological parameters in snails.

\section{Materials and Methods}

The plants used were Agave angustifolia (Family: Agavaceae) and Pittosporum tobira (Family: Pittosporaceae) A. angustifolia was collected from El-Orman Botanical Garden, Giza Governorate, while P. tobira was collected from El-Zohria Garden, Cairo Governorate. Plants were kindly identified by Dr. Wafaa Amer, Professor of Plant Taxonomy, Faculty of Science, Cairo University. They were shade dried and finally powdered with an electrical grinder. Voucher specimens of plants were kept at Department of Medicinal Chemistry, Theodor Bilharz Research Institute.

Biomphalaria alexandrina snails; the Egyptian intermediate host of Schistosoma mansoni were used in this study. They were collected from irrigation cannels in Giza Governorate. They were kept in plastic aquaria filled with dechlorinated tap water under laboratory conditions $\left(25 \pm 2^{\mathrm{O}} \mathrm{C}\right.$; $\left.\mathrm{pH}: 7.4-7.7\right)$ for three weeks before used in the experimental tests.

Schistosoma mansoni cercariae and ova were obtained from previously in- fected B. alexandrina and mice maintained at Schistosoma Biological Supply Center (SBSC), Theodor Bilharz Research Institute (TBRI), Egypt. The ova were exposed to direct light for $15 \mathrm{~min}$. and allowed to hatch to miracidia in a small amount of the dechlorinated water at $25 \pm 2{ }^{\mathrm{O}} \mathrm{C}$.

Molluscicidal Activity Tests: The dry powder of both plants was first evaluated against $B$. alexandrina snails $(8-10 \mathrm{~mm})$ as aqueous suspensions. A serial of gradual concentrations was prepared from the dry powder of each plant on the basis of weight /volume and expressed in terms of ppm (part per million). Three replicates were prepared for each experimental concentration and for control group (each of 10 snails/L). Both exposure and recovery periods were $24 \mathrm{hrs}$ each unless otherwise stated. Standard WHO procedures were followed (WHO, 1993) and determination of $\mathrm{LC}_{50}, \mathrm{LC}_{90}$ and slope function was carried out following Litchfield and Wilcoxon (1949). At the end, death of snails was defined.

Effect of plants on miracidia: To study the miracidicidal activity of both plants, five ml water containing freshly hatched miracidia was mixed with $100 \mathrm{ml}$ of the tested molluscicidal solutions. Also, 100 $\mathrm{ml}$ of clean dechlorinated tap water containing $5 \mathrm{ml}$ freshly hatched miracidia were used as control. Microscopic observations on the movement and mortality of miracidia were recorded at intervals of $1 / 2$, $1,2 \& 3$ hours.

Cercaricidal activity: Five $\mathrm{ml}$ of cercarial solution containing freshly shed cercariae was mixed in a divided Petri dish with $5 \mathrm{ml}$ of double the molluscicidal concentrations from each tested plant (2 replicates were used for each concentration). Control containing only the same volume of dechlorinated water and hatched cercariae was prepared. The movement of cercariae was observed under stereomicroscope after different intervals of time $(1 / 2,1,2,3 \mathrm{hrs})$ and stationary cercariae were considered dead. At the end 
of the experimental time, the total number of miracidia and cercariae and mortality ratio were estimated (El-Deeb, 1996).

Effect of plants on $B$. alexandrina eggs: Fresh $B$. alexandrina eggs were collected by placing thin polyethylene sheets on the water surface of the snail's aquaria and sheets containing egg clutches were daily removed from the aquaria and cut into pieces containing one clutch. After another, 2 days concentrations of $\mathrm{LC}_{50} \&$ $\mathrm{LC}_{90}$ which equal $75,120 \mathrm{ppm}$ of $A$. angustifolia and $65,120 \mathrm{ppm}$ of $P$. tobira were prepared. Each molluscicidal concentration was supplied with $>120$ snails eggs for $24 \mathrm{~h}$. Thereafter, polyethylene sheets containing egg clutches were transferred to dechlorinated water for recovery for another $24 \mathrm{~h}$. Then the viability of eggs was microscopically examined to watch the dead clutch in which all eggs had been killed and the percentage of dead eggs for each concentration was calculated.

Effect of plants on survival, egg laying, reproduction and growth of adult $B$. alexandrina snails: Snail maintenance: Three replicates of each molluscicidal concentration and control were prepared in plastic aquaria $(1.5 \mathrm{~L}$ capacity) each with 20 snails $(8-10 \mathrm{~mm})$. The aquaria were filled with dechlorinated tap water either alone or with the molluscicidal agents tetramin. Each aquarium was supplied with a piece of chalk as a calcium source. White plastic foams were added to the aquaria for egg deposition and water of each aquarium was changed once weekly. The sub- lethal concentrations used of each plant were 20,40 and $60 \mathrm{ppm}$ of $A$. angustifolia and 20,35 and 45 ppm of $P$. tobira.

Estimation of survival, egg laying, reproduction and growth: The number of live snails was recorded at the end of each week. Snail egg clutches deposited on the foam and the walls of the aquaria and the egg content was counted using a dissecting microscope. At the end of each week, surviving snails in each aquarium were dried with filter paper and weighed. The exposure period lasted for 10 successive weeks, then the molluscicidal concentrations were replaced with dechlorinated tap water for another 8 weeks as recovery period (El-Nahas, 2001; El-Sayed et al, 2002).

Calculations: The terms used to express the tested parameters are: Lx, the survivorship or the ratio of surviving snails in each week, while, Mx, represents the egg laying capacity or the mean number of eggs per snail per week. Lx Mx refers to the reproductive rate in each week while $\mathrm{L} \mathrm{Lx} \mathrm{Mx}$ is the total reproductive rate at the end of the experiment. The growth rate was calculated as the difference between weight of snails in each week and the weight of snails in the previous week divided by the number of live snails in this week. The data were statistically analyzed using " $t$ " test and values were expressed as means \pm S.D.

\section{Results}

The results are shown in tables $(1,2,3$ \& 4) and figures $(1 \& 2)$.

Table 1: Comparative susceptibility of adult B. alexandrina exposed to dry powder of Agave angustifolia and Pittosporum tobira plants for $24 \mathrm{~h}$ and $24 \mathrm{~h}$ recovery.

\begin{tabular}{|c|c|c|}
\hline Molluscicidal Concentrations Plants & P. tobira & A. angustifolia \\
\hline $\mathrm{LC}_{50}(\mathrm{ppm})$ & $65(54.166-78.06)$ & $75(62.45-84.36)$ \\
\hline $\mathrm{LC}_{90}(\mathrm{ppm})$ & 120 & 120 \\
\hline Slope & 1.64 & 1.52 \\
\hline Sublethal concentrations $(\mathrm{ppm})$ & & \\
\hline $\mathrm{LC}_{0}$ & 20 & 20 \\
\hline $\mathrm{LC}_{10}$ & 40 & 35 \\
\hline $\mathrm{LC}_{25}$ & 60 & 45 \\
\hline
\end{tabular}


Table 2: Cercaricidal and miracidicidal activity of Agave angustifolia dry powder against S. mansoni cercariae after different exposure times.

\begin{tabular}{|c|c|c|c|c|}
\hline Concentrations & \multicolumn{4}{|c|}{$\%$ Mortality of cercariae after indicated time (h) } \\
\hline & 3 & 2 & 1 & $1 / 2$ \\
\hline $\mathrm{LC}_{50}(65 \mathrm{ppm})$ & 85.98 & 76.22 & 61.25 & 46.39 \\
\hline $\mathrm{LC}_{90}(120 \mathrm{ppm})$ & 88.89 & 84.68 & 76.04 & 68.26 \\
\hline Control & 13.2 & 9.6 & 6.5 & 4.8 \\
\hline Concentrations & \multicolumn{4}{|c|}{$\%$ Mortality of miracidia after indicated time (h) } \\
\hline & 3 & 2 & 1 & $1 / 2$ \\
\hline $\mathrm{LC}_{50}(65 \mathrm{ppm})$ & 79.62 & 65.05 & 56.35 & 45.12 \\
\hline $\mathrm{LC}_{90}(120 \mathrm{ppm})$ & 81.38 & 75.52 & 63.16 & 59.46 \\
\hline Control & 15.7 & 11.3 & 9.7 & 8.5 \\
\hline
\end{tabular}

Table 3: Cercaricidal and miracidicidal activity of Pittosporum tobira dry powder against $S$. mansoni cercariae after different exposure times

\begin{tabular}{|c|c|c|c|c|}
\hline \multirow{2}{*}{ Concentrations } & \multicolumn{4}{|c|}{ \% Mortality of cercariae after indicated time (hr) } \\
\cline { 2 - 5 } & 3 & 2 & 1 & $2 / 1$ \\
\hline $\mathrm{LC}_{50}(75 \mathrm{ppm})$ & 91.51 & 79.81 & 67.95 & 64.1 \\
\hline $\mathrm{LC}_{90}(120 \mathrm{ppm})$ & 93.43 & 85.18 & 77.47 & 65.9 \\
\hline Control & 14.6 & 12.6 & 8.2 & 5.3 \\
\hline Concentrations & $\%$ Mortality of miracidia after indicated time (hr) \\
\cline { 2 - 6 } & 3 & 2 & 1 & $2 / 1$ \\
\hline $\mathrm{LC}_{50}(75 \mathrm{ppm})$ & 80.42 & 74.04 & 46.02 & 30.24 \\
\hline $\mathrm{LC}_{90}(120 \mathrm{ppm})$ & 87.47 & 75.66 & 63.79 & 49.96 \\
\hline Control & 16.5 & 13.3 & 12 & 6.5 \\
\hline
\end{tabular}

Table 4: Effect of molluscicidal concentrations of A. angustifolia and P. tobira on B. alexandrina eggs (3 days) after $24 \mathrm{~h}$.

\begin{tabular}{|c|c|c|c|}
\hline Plant concentrations & \multicolumn{3}{|c|}{ No. of B. alexandrina eggs } \\
& \% Mortality & Dead & Total \\
\hline Control & 0 & 0 & 124 \\
\hline A. angustifolia & & & \\
\hline $\mathrm{LC}_{50}=75 \mathrm{ppm}$ & 57.6 & 76 & 132 \\
\hline $\mathrm{LC}_{90}=120 \mathrm{ppm}$ & 81.8 & 108 & 132 \\
\hline$P$. tobira & & & \\
\hline $\mathrm{LC}_{50}=65 \mathrm{ppm}$ & 30 & 36 & 120 \\
\hline $\mathrm{LC}_{90}=120 \mathrm{ppm}$ & 52.5 & 63 & 120 \\
\hline
\end{tabular}

\section{Discussion}

The lethal concentration ( $\mathrm{LC}_{90}$ and $\mathrm{LC}_{50}$ ) of the dry powder of the two plants against $B$. alexandrina were found to be 120 and $75 \mathrm{ppm}$ for A. angustifolia and 120 and 65 ppm for P. tobira (Tab. 1). Reviewing the current literature showed that (to the best of our knowledge), this is the first report on the molluscicidal (Abdel Kader et al, 2005). Besides, mollusciciding, another approach to the control of schistosomiasis is to attack the free larval stages of schistosomiasis i.e cercariae and miracidia. Being sensitive, these organisms can be used as a vulnerable target for the interruption of schistosomiasis life cycle (Ragab et al, 2003). Concerning the miracidicidal and cercaricidal activities of A. angustifolia and P. tobira, (Tabs. 2, 3), it was found that both plants have strong toxic effect on miracidia and cercariae of S. mansoni. However, A. angustifolia has a higher effect than $P$. tobira, as $\mathrm{LC}_{90}=93.43 \%$ of cercariae and $87.47 \%$ of miracidia were killed after 3 hours of exposure to $A$. angustifolia plant. For $P$. tobira, cercaricidal \& miracidicidal mortality were $88.89 \%$ and $81.36 \%$ after 3 hours of exposure. These results agreed with those of (Abdel-Kader et al, 2005) 
who observed that sub lethal concentrations of two other Agave species; A. filifera and $A$. attenuate killed $100 \%$ of cercariae and miracidia of $S$. mansoni after 6 hours of exposure. Medina et al. (2009) reported on the strong cercaricidal activity of Croton floribundus hexane and ethanol extract. It was, also, noticed that the cercaricidal and miracidicidal potencies of both plants follows a time-concentration relationship pattern. This observation is in good accordance with Singab et al., (2006) on flavonoids isolated from Egyptian Iris germanic. As the parasite multiplies into hundreds of cercariae that can penetrate the intact human skin after leaving the snails, therefore, molluscicides that possess dual effect as larvicidal beside molluscicidal impact is another interesting feature of the plant (Medina et al, 2009).

Activity against both adult and egg stages of vector snails is considered one of the most important aspects of any efficient molluscicide that is to be used in the control of schistosomiasis (Abdel Kader and Sharaf El-Din, 2000; Fayez et al, 2013).

In the present study, the aqueous suspension of both plants was active against $B$. alexandrina eggs (Tab. 4). Regarding the ovicidal activity of the two plants against three days-old $B$. alexandrina eggs, A. angustifolia had higher ovicidal activity than $P$. tobira. The mortality rates of the eggs were $81.8 \%$ and $52.5 \%$ after $24 \mathrm{~h}$ of exposure to $120 \mathrm{ppm}$ of the two plants, respectively. These results agree with Allam et al. (2001), who found $100 \%$ mortality was obtained for the egg clutches of $B$. alexandrina at concentration of $100 \%$ ppm of the oil extract of Commiphora molmol (Myrrh). Also, Massoud et al. (2004) proved that one day-old egg masses were more susceptible to the ovicidal effect of Myrrh than 5 days-old ones and eggs were all killed at $80 \mathrm{ppm}$. The ovicidal toxicity of the tested plants was reported that the n-butanol extracts of some plants molluscicide like
Sapindus trifoliatus, Agave Americana, Balanites aegyptiaca and Vaccaria pyranidata as toxic against freshly laid eggs. The ovicidal action of the 2 plants against $B$. alexandrina snails showed that the two plants are slightly more toxic to the snails than to the 3 days-old eggs. This means that eggs were less susceptible than adult snails which may be due to the covering capsular jelly like materials that covers and protect the laid eggs from the external environment. Similar observations were reported for extracts from different parts of some species of Annona (Dos Santos and Sant Ana, 2001).

On the contrary, some other plant molluscicides like Ambrosia moritima, Tetrapleura tetraptera were reported to exhibit very lower toxicity towards earlier developmental stages than adults. Even Endod, the most promising plant molluscicide is devoid of ovicidal properties (Sukumaran et al, 2004). Following the positive results regarding the high molluscicidal properties of the dry powder of the tested plants, $B$. alexandrina snails were subjected to sub lethal concentrations of these plants during 18 consecutive weeks (Figs 1, 2). Concerning the effect of sublethal concentrations (low and high) of $A$. angustifolia and P. tobira on the survival rate, egg laying capacity and growth rate of B. alexandrina snails, data showed that continuous and gradual decline in survival rate at 20 and $40 \mathrm{ppm}$ of A. angustifolia were recorded. Meanwhile snails exposed to high concentration $(60 \mathrm{ppm})$ of the plant showed faster and sharp depression in survival rate and all exposed snails were dead after 4 weeks of experiment.

Snails exposed to $20 \& 35 \mathrm{ppm}$ of $P$. tobira recorded a continuous decline in the survival rate (Lx) during the exposure period (10 weeks) while snails exposed to $45 \mathrm{ppm}$ of this plant recorded a steady and gradual decline till the end of experiment. This mean that the cumulative toxic action of $60 \mathrm{ppm}$ of $A$. angustifolia was greater than the other concentrations is 
survivorship recorded after 4 weeks was zero which was much lower than any other treated group this prohibition action on the survival rate was similar to that noticed by other researches (El-Deep and El-Nahas, 2002).

Also, the sublethal concentration of Atriplex halimus were reported to cause reduction in survival rates of $B$. alexandrina (Tantawy, 2002). Regarding the egg laying capacity $\left(\mathrm{M}_{\mathrm{x}}\right)$, the reproductive rate $\left(L_{x} M_{x}\right)$, the total fecundity $\left(\sum M_{x}\right)$ and the total reproductive rates $\left(\sum \mathrm{L}_{\mathrm{x}} \mathrm{M}_{\mathrm{x}}\right)$ by the end of experiment; the data recorded showed that snails exposed to the two plants recorded different responses. As for the snails treated with $20 \& 40$ ppm of $A$. angustifolia, the fecundity values were fluctuating during most weeks of the experiment. Meanwhile, snails continued to lay eggs during all the experiments and the total fecundity $\left(\sum \mathrm{M}_{\mathrm{x}}\right)$ was higher than that of the control. On the other hand, the snails treated with 60 ppm recorded lower values of $\left(\mathrm{M}_{\mathrm{x}}\right)$ than control during the 4 weeks because snails died after this period.

Abdel Kader et al. (2005) reported that Agave filifera and Agave attenuate inhibited egg production and induced marked increase in the percent of abnormal laid eggs. Exposing snails to P. tobira greatly impair reproduction ability of exposed snails throughout most of the observation weeks. This suppressive effect induced on reproduction efficacy agreed with the effect of other plants on the same snail species (Mostafa and Tantawy, 2000) and on other Biomphalaria species, as B. glabrata (Ragab et al, 2003).

Meanwhile, the slight improvement of reproduction ability by the end of the experiment means that snails tried and succeeded to overcome the destructive effect of the plants as a defense mechanism. It was also, observed that in all treated groups, total inhibition in eggs output was not recorded at any of the observation weeks. This difference in response between snails exposed to plant and syn- thetic molluscicides could be attributed to that synthetic molluscicides have more destructive effect on reproduction capacity than botanical ones (El-Deeb and ElNahas, 2002).

The reduction in total fecundity means that the snail's reproductive capacity may almost be destroyed owing to the effect of the herbal molluscicide on ovotestis. This agrees well with Singh and Singh, (2004), and Singh et al. (2005), who reported that sublethal concentrations of some botanical molluscicides caused great decrease in protein, amino acid, DNA and RNA in the ovotestis of treated snails. These elements are very important in several metabolic processes including gamesomeness.

Another explanation was that these herbal molluscicides may greatly inhibit the secretion of steroidal sex hormones responsible for maturation of the hermaphrodite gland and stimulation of gamesomeness (El-Nahas, 1998). It was also noticed that, the suppressive effect on both egg laying capacity and reproductive rate is a dose-dependent. This notice is in full accordance with other reported data (Rao and Singh, 2000). The net growth rate of snails treated with the two plants $A$. angustifolia and P. tobira showed lower values in some groups than that control group. The great inhibition in growth rates of snails treated with the molluscicidal plants could be attributed to possible disturbance in metabolism or physiology of snails (Abdel Kader et al, 2005). The results in this study also, proved that the reduction in snail's growth rate was directly proportional to the concentrations used. This finding is in accordance with other reports on other plant molluscicides on the same snail species (El-Deeb and El-Nahas, 2002; ElNahas and El-Deeb, 2007; El-Sayed et al, 2011; Abdalla et al, 2012; Fayez et al, 2013).

\section{Conclusion}

No doubt, schistosomiasis and its complications is a public health problem. On 
the other hand, the chemical molluscicides are risky to man and environment. Plants' molluscicides are more safe to man and environment. The outcome results showed that Agave angustifolia and Pittosporum tobira are promising molluscicides for schistosomiasis

\section{References}

Abd Allah, KF, Negm-Eldin, MM, Saleh, MH, El-Hamshary, AM, El-Gozamy, B M, et al, 2009: A study on biological control of six fresh water snails of medical and veterinary importance. J. Egypt Soc. Parasitol. 39:121-39.

Abdalla, AH, Abeer EM, Rasha AH, Enas AM, 2012: Evaluation of the ethanolic extracts of three plants for their molluscicidal activities against snails intermediate hosts of Schistosoma mansoni and Fasciola. Int. J. Basic Appl. Sci. 1:235-49.

Abdel Kader, A, Hamdi, SAH, Rawi, SM, 2005: Biological and biochemical studies on Biomphalaria alexandrina snails, treated with low concentration of certain molluscicides (synthetic and of plant origin). J. Egypt. Soc. Parasitol. 35, 3:84158.

Abdel Kader, A, Sharaf El-Din, A, 2000: Potency of copper sulphate, Bayluscide, Calendula micrantha officinalis and Ammi majus flowers on egg masses of Biomphalaria alexandrina and Bulinus truncatus. Egypt. J. Schist. End. Infect. Dis. 22:15973.

Abebe, F, Erko, B, Gemetchu, T, Gundersen, SG, 2005: Control of Biomphalaria pfeifferi population and schistosomiasis transmission in Ethiopia using the soap berry endod (Phytolacca dodecan$d r a$ ), with special emphasis on application methods. Trans. Roy. Soc. Trop. Med. Hyg. 99:787-94.

Adewunmi, CO, Aladesanmi, AJ, 2006: Molluscicidal activities of Dysoxylum lenticellare gillespie constituents on Biomophalaria glabrata say Phytother. Res. 2: 104-6.

Ahmed, HA, Awatif, AE, Waleed, SK, Elbadri, EO, Mahmoud, MD, 2014: In Vitro anticercarial activities of some Sudanese medicinal plants of the family Combretaceae. J. Forst Prod. Indust. 3, 2:93-9.
Allam, AF, El-Sayed, MH, Khalil, SS, 2001: Laboratory assessment of the molluscicidal activity of Commiphora molmol (Myrrh) on Biomphalaria alexandrina, Bulinus truncatus and Lymnaea cailliaudi. J. Egypt Soc. Parasitol. 31, 2:683-90.

Dos Santos, AF, Sant'Ana, AE, 2001: Molluscicidal properties of some species of Annona. Phytomed. 8:115-20.

El-Deeb, FA, El-Nahas, HA, 2002: Effect of low and prolonged molluscicidal concentrations against Biomphalaria alexandrina snails and its Schistosoma infections. Egypt. J. Agric. Biol. Fish. 6:27-46.

El-Nahas, HA, El-Deeb, FA, 2007: Molluscicidal potency of Pittosporum tobira varigatum and Hedera canariensis plants against juvenile and adult Biomphalaria alexandrina snails. Egypt. J. Aquat. Fish. 11:151-74.

El-Sayed MM, El-Nahas HA, El-Wakil EA, El-Shazly MA, 2002: Preliminary evaluation of some local plants as molluscicides. Womens College Ann. Rev. 21:5568.

El-Sayed, MM, Mahmoud, MA, El-Nahas, HA, El-Toumy, SA, El-Wakil, EA, et al, 2011: Chemical constituents, antischistosomal and antioxidant activity of methanol extract of Azadirachta indica. Egypt. J. Chem. 54:105-19.

Erko, B, Abebe, F, Berhe, N, Medhi, G, Gebre-Micheal, T, et al, 2002: Control of Schistosoma mansoni by the soapberry Endod (Phytolacca dodecandra) in Wollo, Northeastern Ethiopia-post intervention prevalence. East. Afri. Med. J. 79:198-201.

Fayez, AB, Abd El-Atti, MS, Somaya, M I, 2013: Effect of Zingiber officinal (ginger) on electrophoresis analysis and biochemical aspects of Biomphalaria alexandrina snails infected with Schistosoma mansoni. Int. J. Sci. Eng. Res. 4, 11:1147-54.

Jean-Jacques, MB, Laurence, VN, Charlotte, S, Augustin, SB, Jean-Piere, BB, 2014: Evaluation of Schistosoma mansoni cercaricidal activity of Solamargine a steroid glycoalkaloid from Solanum syzybrilifolium. Int. J. Eng. Res. General Sci. 2, 1: 15-23.

Litchfield, J, Wilcoxon, F, 1949: A simplified method of evaluating doseeffect ex- 
periments. J. Pharmac. Exp. Therap. 96:99113.

Massoud, A, Metwally, DM, Khalifa, K E, Habib, FS, 2004: Compatibility of Biomphalaria alexandrina snails to infection with Schistosoma mansoni after exposure to sublethal concentrations of Myrrh. J. Egypt Soc. Parasitol. 34, 3:995-1008.

Medina, JM, Peixoto, JL, Silva, AA, Haraguchi, SK, Falavigna, LM, et al, 2009: Evaluation of the molluscicidal and Schistosoma mansoni cercariae activity of Croton floribundus extracts and Kaurenoic acid. Braz. J. Pharmacog. 19:207-11.

Mortada ME, Hanan AE, Eman AE, 2014: Molluscicidal properties and chemical constituents of Euphorbia peploides. Australian J. Basic Appl. Sci. 8, 3:541-8. Mortada, ME, Ahmed, MA, Abdel-Nasser, AS, Mahar, AM, Eman, AE, et al, 2011: Effect of Ficus sycomorus and Azadirachta indica extracts on liver state of mice infected with Schistosoma mansoni. J. Egypt. Soc. Parasitol. 41, 1:77-88.

Mostafa BB, El-Deeb FA, Ismail, NM, EI-Said, KM, 2005: Impact of certain plants and synthetic molluscicides on some fresh water snails and fish. J. Egypt Soc. Parasitol. 35, 3:989-1007.

Mostafa, BB, Tantawy, AA, 2000: Bioactivity of Anagallis arvensis and Calendula micrantha plants treated with ammonium nitrate, superphosphate and potassium sulphate fertilizers on Biomphalaria alexandrina. J. Egypt. Soc. Parasitol. 30:929-42.

Ragab FM, El-Khayat, HM, Mostafa, B B, Gawish, FA, 2003: Difference in the susceptibility to Schistosoma mansoni infection of three forms of Egyptian Biomphalaria glabrata. J. Egypt Soc. Parasitol. 33, 3:743-60.

Rao, IG, Singh, DK, 2000: Effect of single and binary combinations of plantderived molluscicides on reproduction and survival of the snail Achatina fulica.
Arch. Environ. Contam. Toxical. 39:48693.

Silva, TM, Batista, MM, Camara, CA, Agra, MF, 2005: Molluscicidal activity of some Brazilian Solanum spp. (Solanaceae) against Biomphalaria glabrata. Ann. Trop. Med. Parasitol. 99:419-25.

Singab, AB, Ahmed, AH, Sinkkonen, J, 2006: Molluscicidal activity and new flavonoids from Egyptian Iris gremanica L. (var. alba). Z. Nalurforsch. 61:57-63.

Singh, A, Singh, DK, 2004: Effect of herbal molluscicides and their combination on the reproduction of the snail $L y$ mnaea acuminata. Arch. Environ. Conatam. Toxicol. 46:470-7.

Singh, SK, Yada, RP, Tiwari, S, Singh, A, 2005: Toxic effect of stem bark and leaf of Euphorbia hirta plant against fresh water vector snail Lymnaea acuminata. Chemosphere 59:263-70.

Sparg, SG, Van Staden, J, Jager, AK, 2000: Efficiency of traditionally used South African plants against schistosomiasis. J. Ethnopharmacol. 73:209-14.

Sukumaran, D, Parashar, BD, Gupta, AK, Jeevoratnam, K, Prakash, S, 2004: Molluscicidal effect of nicotinanilide and its intermediate compounds against a fresh water snail Lymnaea luteola, the vector of animal schistosomiasis. Mem. Inst. Oswaldo Cruz. 99:205-10.

Sukumaran, D, Parashar, B, Rao, K, 2002: Evaluation of some plant molluscicides against the fresh water snail Lymnaea luteala, the vector of animal schistosomiasis. Pharm. Biol. 40:450-5.

Tantawy AA, 2002: Effect of sublethal concentrations of Atriplex halimus (Chenopodiaceae) on Biomphalaria alexandrina, the snail vector of Schistosoma mansoni in Egypt. J. Egypt Soc. Parasitol, 32:297-305. WHO, 1993: The control of schiastosomiasis. $2^{\text {nd }}-$ Report of the WHO Expert Committee, Tech. Rep. Ser., 830: 1-80. 


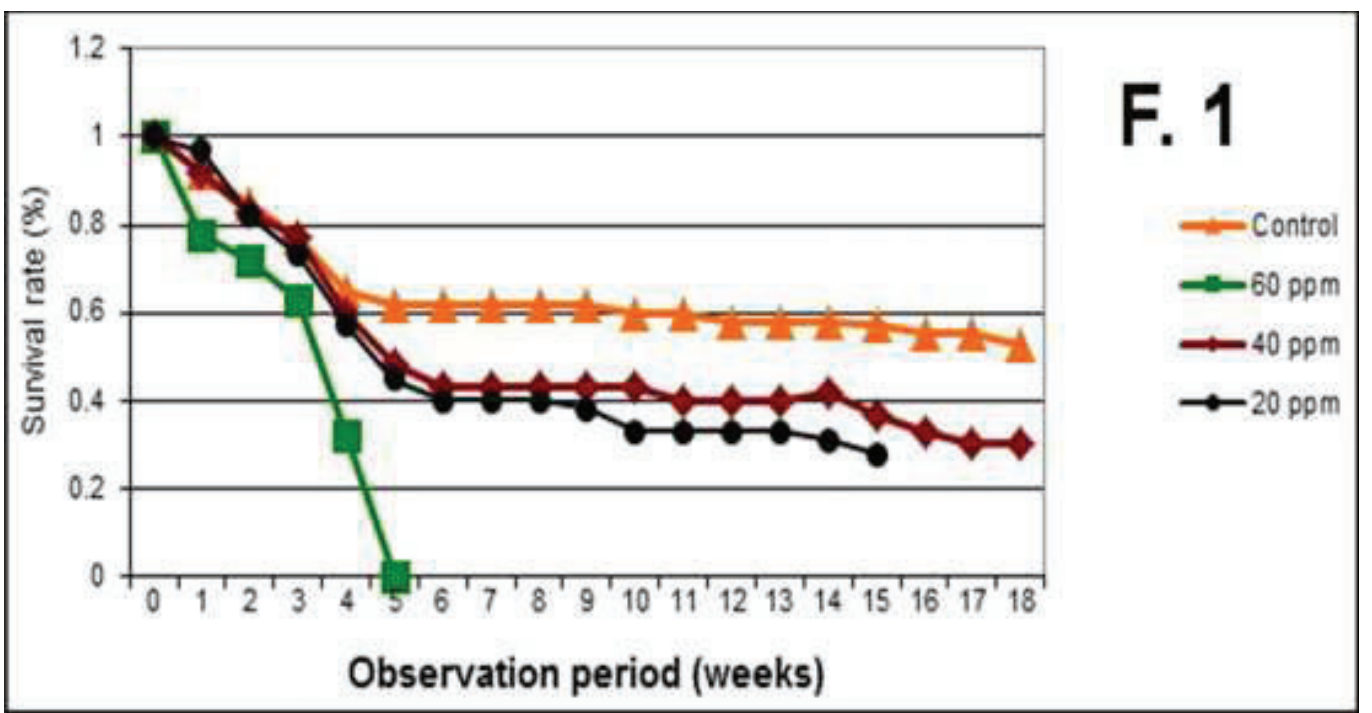

Fig. 1: Survivorship $\left(\mathrm{L}_{\mathrm{X}}\right)$ of adult Biomphalaria alexandrina snails exposed to sublethal concentrations of Agave angustifolia for 18 successive weeks

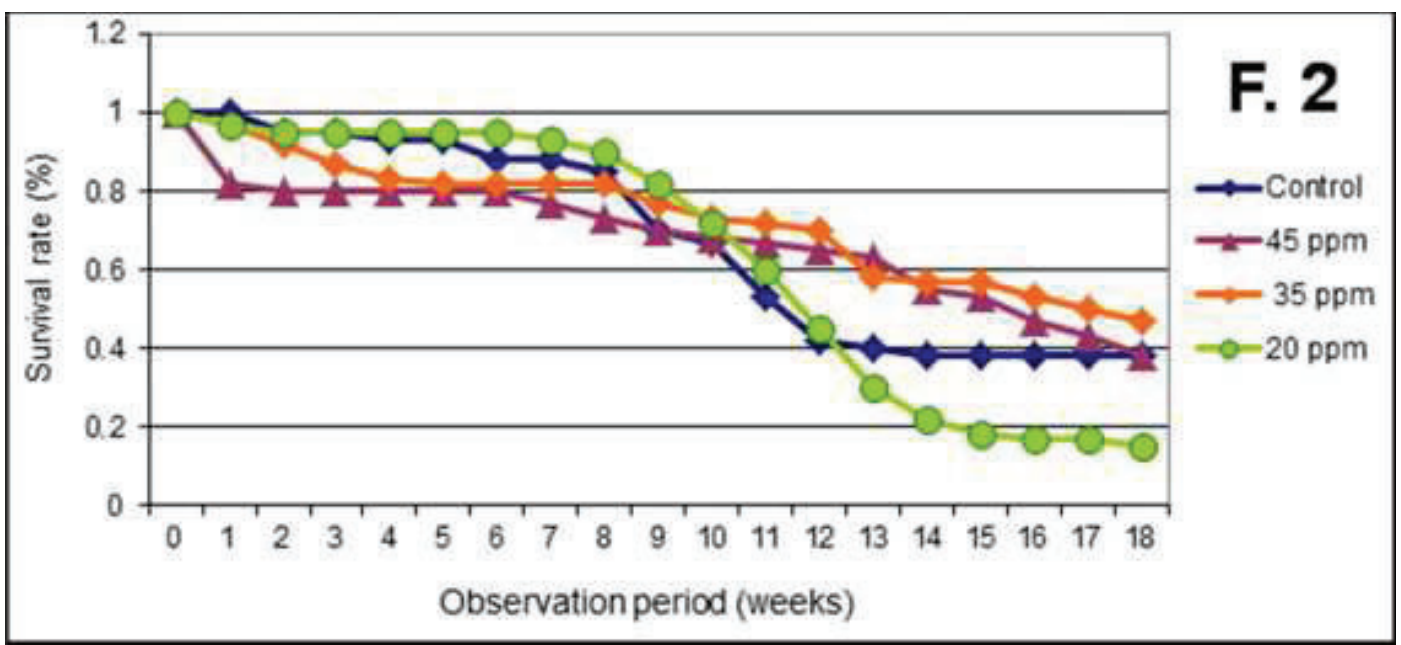

Fig. 2: Survivorship $\left(\mathrm{L}_{\mathrm{X}}\right)$ of adult Biomphalaria alexandrina snails exposed to sublethal concentrations of Pittosporum tobira for 18 successive weeks. 